\title{
A Search for Wisdom
}

\section{Citation}

Kleinman, Arthur Michael. 2011. A search for wisdom. The Lancet 378(9803): 1621-1622.

\section{Published Version}

doi:10.1016/S0140-6736(11)61688-7

\section{Permanent link}

http://nrs.harvard.edu/urn-3:HUL.InstRepos:9366599

\section{Terms of Use}

This article was downloaded from Harvard University's DASH repository, and is made available under the terms and conditions applicable to Open Access Policy Articles, as set forth at http:// nrs.harvard.edu/urn-3:HUL.InstRepos:dash.current.terms-of-use\#OAP

\section{Share Your Story}

The Harvard community has made this article openly available.

Please share how this access benefits you. Submit a story.

\section{Accessibility}


Filename: (in Papers: Lancet) Kleinman-Lancet-Search-Wisdom-submission-9-27-2011.docx

FOR SUBMISSION TO THE LANCET

"An Unfulfilled, and yet not Unfulfillable, Search for Wisdom: Philosophy, Anthropology, Medicine, Love and Loss"

Arthur Kleinman

Harvard University

27 September 2011

For Joan Andrea Kleinman, 4 September 1939-6 March 2011

In my late 20s, during those years when I served as a U.S. Public Health Service officer and NIH Fellow stationed in Taiwan (1969-1970), I kept a journal that was filled with pithy quotations from the reading I was then doing of early $20^{\text {th }}$ Century Continental philosophers, including Bergson, Dilthey, Husserl, Merleau-Ponty, Cassirer, and Ortega y Gasset. There were also in those pages the words of American pragmatists, especially John Dewey, but including William James. I reopened the scarred, yellowed pages of the journal and reread those short 
excerpts again in Spring 2011, following the death of my wife and collaborator, the sinologist Joan Kleinman, with whom I had lived and loved for almost a half century. I was experiencing uncontrollable memories of our past together, while struggling to come to terms with a great sadness oscillating with aching yearning that felt like a heavy stone was weighing down my soul. In those early weeks of loss, I was devastated and quite literally lost. Focusing on the journal's oracular entries, I knew even then was probably going to be a largely unsuccessful attempt to sublimate unmasterable feelings of grief. On rereading these philosophical selections, I became acutely, even embarrassingly, aware that 43 years before I had also been on a failed quest to go beyond what intellectual authority and legitimacy these statements could offer for practical wisdom about how to live. At that earlier time, I needed to have my inchoate ideas, which had begun to feel overreaching and unreal, supported by a lineage of thought. I needed an intellectual and, in another sense, moral foundation. In 1969, I was about to make what I knew would be a decisive turn away from the laboratory and the primary care clinic that would carry me back toward the humanities, which had been my undergraduate academic home, and ahead toward anthropological fieldwork and psychiatric practice, the uncertain consequences of which I could barely appreciate other than as aspiring and anxious dreams. I had come to feel stifled and frustrated, and I wanted wisdom to furnish my career and animate my life with a compelling agenda, a great idea and a means of calming the unsettling restlessness that I felt, which returned at the time I reread the journal following Joan's death.

If I have managed to confuse the reader about the two, so different eras, that confusion is what I too experienced. I needed, in both periods, reassurance, confirmation that the very 
grounds of who I was and what I was doing were real, stable, and appropriate for a professional intellectual career and for the deep subjectivity of my life. I had set out in 1969 to rethink medicine as a cultural phenomenon and illness as suffering, a moral experience. I knew others thought this approach to health and medicine as questions in the development of a grounding social theory to be fantastically presumptuous and even impossible. And following Joan's death, I was back in the seething, inchoate morass of my feelings, agitated and obsessed by the absence of clear markers and by something much bigger - the loss of something so miraculous, so definitive that I could not imagine getting through the rest of life without it. The all-absorbing love I had for my wife, and she for me, had more than sustained me and her through those uncertain years of building a subject and a family and our own a world. That fierce and joyful love had animated those years, now gone forever, with a golden hue that expressed a shared sensibility of things being right and good and beautiful. During the terrible years of Joan's descent through neurodegeneration to blindness, dementia, paralysis and a slow death, love had made it possible to endure the unendurable; it had motivated my caregiving and her carereceiving.

No wonder I went back to find something of that earlier time that I could hold on to and be inspired by, or at least work with.

"The historical categories of value and purpose grow out of lived experience." -Dilthey

And so on; for the quotations go on and on for dozens of densely written pages. 
I had (and still have) an affinity for philosophers concerned with phenomenological reality and existential themes. These philosophers were appealing to me in part for highly personal reasons and in part because they were a bridge to social theorists whose work I used to develop my own theories of illness experience, social suffering, stigma, and medicine as a moral enterprise. Creating a file of congenial philosophers whose insights I found attractive led to a now abiding sensibility that theory matters, not mainly for the sake of ideas, but principally, because it illuminates, makes coherent and redirects empirical studies and their practical implications so that there are real effects in the world that are original and against the grain.

Of course, working with philosophical positions and arguments fit my temperament and the deep desire I have held since adolescence to be intellectually serious, and to be taken by others as such. It informed both the professional and domestic conversations Joan Kleinman and I built. What philosophical insights didn't do for me was to offer up the deep wisdom I was searching for, first in 1969, and once again in 2011. Neither in understanding my career crisis nor in appreciating the joys and pains of love, nor still in making sense of the existential body blow of loss, did these writers and their ideas offer a wisdom that I could apply to grapple with disappointment and defeat. Of course to be fair, neither did religious writings and practices, poetry, or any other source code offer me help in this way.

The quest itself, I now see, could not but fail. The cultural expectation could not be advanced, nor the private one realized, because the object of enquiry was wrong. It wasn't understanding life as perception, nor illness as symbol, not even medicine as cultural form that mattered at these times of crisis. 
I can't even say that moralists — whose rightfully famous works I had spent so many hours with, which were otherwise so helpful in making me realize that experience is always and everywhere a moral condition of what is most at stake for individuals amidst the uncertainties and dangers of ordinary times--fulfilled what I was most after. I wished to see my own subjectivity—self, sensibility, commitments, will—experienced not as moral theory, but as authorizing feelings and values that could sustain my engagement in the world and connect me to others who mattered to me. Hence my deep subject was not experience as a philosophical problem, albeit that was not irrelevant; it was experience as practice that I was after. And such practice is always about action among others, upon others, best of all, for others. It is through mentoring and caregiving - as doctor and teacher - that I have come closest to finding the object of my quest for wisdom. It is also what I was seeking so unsuccessfully in what I would now call my romantic reading of important thinkers, which William James referred to as a quest for "the strangely moving power of passages...irrational doorways as they were through which the mystery of fact, the wildness and the pang of life, stole into our hearts and thrilled them". My search for a wisdom had been a largely unfulfilled quest, but as in the case of caregiving, not an unfulfillable one.

And it is here that William James has been especially important to me. My reading of James' extraordinary prose-filled with resonant images, mobilizing cadences and striking metaphors and alive with his vulnerable yet robust humanity - invited a freedom of interpretation and dialogical flights of ideas/feelings that have given me over four decades a large happiness and strong significance. I needed someone with some set of useful ideas not to free up within me 
my own music, but to co-create that music in a long-term dialogue, through a creative back and forth from metaphor to rhythm of words to findings from experience to major conclusions relevant to my life.

I needed an intellectual interlocutor who could come right down into my experience and illuminate it from within. It could have been Montaigne or Shakespeare and other strong poets. For me it was the author of The Varieties of Religious Experience and the great Principles of Psychology. James spoke; I felt the words strike home. In some uncanny and yet not unordinary way, James' shoved me. It was not exactly what he said, nor some specific answer he provided to my originating questions, but rather a feeling that emerged from the exchange that for me mattered most and that propelled me along my way.

"If this life be not a real fight, in which something is eternally gained for the universe by success, it is no better than a game of private theatricals from which one may withdraw at will. But it feels like a real fight—as if there were something really wild in the universe which we, with all our idealities and faithfulnesses, are needed to redeem"

-William James, The Varieties of Religious Experience

I had in my memory my wife's death mask, the fine skin pulled tight across her high cheeckbones, her unseeing eyes, her final breath, and the feeling that I was floating away, no longer anchored. I had a real fight on my hands, and in my being. The wisdom I needed came out of my readiness to respond to James's pushing at a certain time when I was faced with a problem central to the human condition: a problem that connected me up with the grain of life and with the existential uncertainty of our being. And that fostered a feeling of recognition and recovery. 
And that is how it perhaps always works. Wisdom needs to be experienced to be effective, and is effective not as an idea, but as a lived feeling and a moral practice that redeems our humanness amidst inevitable disappointment and defeat. Perhaps just so does our readied response at times of deep trouble and anguish to paintings, music, and works in the humanities redeem the felt moral experience of the doctor and the patient in the family — I am here all three-while the impossible fight over life goes on and the quest for wisdom remains ordinarily unfulfilled, yet over time not unfulfillable. 